\title{
Suture technique does not affect hemodynamic performance of the small supra-annular Trifecta bioprosthesis
}

\author{
Murat Ugur, MD, ${ }^{\mathrm{a}}$ John G. Byrne, MD, MBA, FACC, ${ }^{\mathrm{b}}$ Joseph E. Bavaria, MD, ${ }^{\mathrm{c}}$ Anson Cheung, MD, ${ }^{\mathrm{d}}$ \\ Michael Petracek, MD, ${ }^{\mathrm{e}}$ Mark A. Groh, MD, ${ }^{\mathrm{f}}$ Rakesh M. Suri, MD, DPhil, ${ }^{\mathrm{a}}$ Michael A. Borger, MD, ${ }^{\mathrm{g}}$ and \\ Hartzell V. Schaff, MD ${ }^{\mathrm{a}}$
}

Objective: The study objective was to evaluate whether aortic valve replacement with the Trifecta valve (St Jude Medical Inc, St Paul, Minn) using simple sutures produces better hemodynamic performance than valve replacement with noneverting pledget-reinforced sutures.

\begin{abstract}
Methods: We analyzed prospectively acquired 1-year hemodynamic data of patients with small aortic annulus sizes who were enrolled in a multicenter trial of the Trifecta aortic valve bioprosthesis and underwent aortic valve replacement with a 19-mm or 21-mm bioprosthesis between August 2007 and November 2009. We compared preoperative clinical information and 1-year postoperative hemodynamic data for noneverting pledget-reinforced sutures (group 1) versus everting mattress sutures or simple sutures (group 2).

Results: A total of 346 patients underwent aortic valve replacement: 269 in group 1 and 77 in group 2. Preoperative demographic characteristics for the 2 groups were similar. For groups 1 and 2, the mean gradient was 10.4 $\pm 4.7 \mathrm{~mm} \mathrm{Hg}$ and $11.1 \pm 4.4 \mathrm{~mm} \mathrm{Hg}$ for $19-\mathrm{mm}$ valves, respectively, and $8.4 \pm 3.5 \mathrm{~mm} \mathrm{Hg}$ and $8.8 \pm 3.6 \mathrm{~mm} \mathrm{Hg}$ for 21-mm valves, respectively; the effective orifice area was $1.40 \mathrm{~cm}^{2}$ and $1.25 \mathrm{~cm}^{2}$ for $19-\mathrm{mm}$ valves, respectively, and $1.57 \mathrm{~cm}^{2}$ and $1.50 \mathrm{~cm}^{2}$ for $21-\mathrm{mm}$ valves, respectively. The rate of severe prosthesis-patient mismatch (indexed effective orifice area $\left.\leq 0.65 \mathrm{~cm}^{2} / \mathrm{m}^{2}\right)$ was $18.6 \%(\mathrm{n}=11)$ and $25 \%(\mathrm{n}=6)$ for $19-\mathrm{mm}$ valves, respectively, and $10.9 \%(\mathrm{n}=20)$ and $16.3 \%(\mathrm{n}=8)$ for $21-\mathrm{mm}$ valves, respectively.
\end{abstract}

Conclusions: The suture method did not affect hemodynamic performance of supra-annular bioprostheses in patients with small aortic annulus sizes. Choice of suture technique should be determined by surgeon experience and local anatomic features. (J Thorac Cardiovasc Surg 2014;148:1347-51)

Many variables may affect the hemodynamic performance of the aortic valve bioprosthesis, including stent and sewing ring design. The hemodynamic function of the third-generation supra-annular stented bioprosthesis is

From the Division of Cardiovascular Surgery, ${ }^{\text {a }}$ Mayo Clinic, Rochester, Minn; Division of Cardiac Surgery, ${ }^{\mathrm{b}}$ Brigham and Women's Hospital, Boston, Mass; Division of Cardiovascular Surgery, ${ }^{\mathrm{c}}$ Hospital of the University of Pennsylvania, Philadelphia, Pa; Division of Cardiac Surgery, ${ }^{\mathrm{d}}$ St Paul's Hospital, University of British Columbia, Vancouver, British Columbia, Canada; Department of Cardiac Surgery, Vanderbilt University Medical Center, Nashville, Tenn; Cardiovascular and Thoracic Surgery, ${ }^{\mathrm{f}}$ Mission Health, Asheville, NC; and Department of Cardiac Surgery, ${ }^{\mathrm{g}}$ Leipzig Heart Center, Leipzig, Germany.

The study was supported by St Jude Medical Inc (St Jude Medical Inc, St Paul, Minn). Disclosures: The authors were investigators in the Food and Drug Administrationmandated clinical trial of the small supra-annular Trifecta (St Jude Medical Inc) aortic valve bovine bioprosthesis. Joseph E. Bavaria reports consulting fees from W. L. Gore and lecture fees from St Jude and Medtronic Vascular. Anson Cheung reports consulting fees from St Jude, Edwards, and Medtronic and equity ownership in Entourage Medicals and Neovasc Inc. Mark A. Groh reports consulting fees from St Jude. Rakesh M. Suri reports consulting fees from Sorin (Percival Trial PI and patent applications), and grant support from Edwards, Sorin, and St Jude. Michael A. Borger reports lecture fees from St Jude, Edwards, and Medtronic. All other authors have nothing to disclose with regard to commercial support. The Mayo Clinic does not endorse the products mentioned in this article.

Received for publication Sept 12, 2013; revisions received Nov 15, 2013; accepted for publication Dec 5, 2013; available ahead of print Feb 8, 2014.

Address for reprints: Hartzell V. Schaff, MD, Division of Cardiovascular Surgery, Mayo Clinic, 200 First St SW, Rochester, MN 55905 (E-mail: schaff@ mayo.edu). $0022-5223 / \$ 36.00$

Copyright (C) 2014 by The American Association for Thoracic Surgery http://dx.doi.org/10.1016/j.jtcvs.2013.12.006 generally similar to that of stentless valves. ${ }^{1}$ Also, suture technique may affect the hemodynamic outcome of aortic valve replacement (AVR). In patients with a small aortic annulus (with or without augmentation), a slightly larger prosthesis may be possible when a simple suture technique is used instead of a mattress suture technique, which can reduce annular diameter by $1 \mathrm{~mm}$ or more. ${ }^{2}$ Thus, use of simple sutures may decrease the likelihood of prosthesispatient mismatch (PPM) in at-risk patients.

Some surgeons believe that noneverting mattress sutures with pledget reinforcement can further impair hemodynamic function of the prosthesis by drawing tissue toward the valve orifice and potentially contributing to transvalvular gradient and predisposing to pannus formation. ${ }^{3,4}$ In an analysis of 152 patients with small aortic annuli who underwent AVR with the Carpentier-Edwards Perimount Magna (Edwards Lifesciences Corp, Irvine, Calif) bioprosthesis, Tabata and colleagues ${ }^{4}$ reported that the simple interrupted suture technique yielded better hemodynamic function than noneverting sutures. To better understand the potential impact of suture method on prosthetic valve hemodynamics in North American and European populations, we reviewed the 1-year Doppler echocardiographic data of patients who underwent AVR with the 19-mm or $21-\mathrm{mm}$ Trifecta bioprosthesis (St Jude Medical Inc, St Paul, Minn). 


\section{Abbreviations and Acronyms \\ AVR $=$ aortic valve replacement \\ $\mathrm{EOA}=$ effective orifice area \\ EOAI $=$ effective orifice area index \\ LVOT $=$ left ventricular outflow tract \\ PPM = prosthesis-patient mismatch \\ TVI $=$ time-velocity integral}

\section{MATERIALS AND METHODS}

We analyzed prospectively acquired data from the US Food and Drug Administration investigational device exemption study of the Trifecta aortic valve bovine bioprosthesis. Details of the multicenter study and participating sites have been published. ${ }^{5}$ We included patients who received a $19-\mathrm{mm}$ or $21-\mathrm{mm}$ valve and divided them into 2 groups by type of suture technique. Group 1 included patients in whom the aortic valve prosthesis was secured using noneverting pledget-reinforced mattress sutures; 12 to 16 pledgeted polyester sutures were passed from the ventricular side of the annulus through the aortic side and through the prosthetic valve sewing ring. Group 2 included patients who had their aortic valve prosthesis implanted using suture techniques that avoided gathering tissue beneath the valve (everting mattress sutures with or without pledgets, simple sutures, or continuous suture techniques). The Food and Drug Administration protocol did not prescribe an implant method, so the suture technique was determined by the implanting surgeon. Demographic and clinical information that was collected included the suture technique, late survival, reoperation, and reports of Doppler echocardiograms.

We compared preoperative demographic and hemodynamic data of the 2 groups and focused on 1-year postoperative Doppler echocardiographic data (eg, mean gradient, effective orifice area [EOA], and EOA index [EOAI]), which is computed by dividing the EOA by the body surface area. All Doppler echocardiograms were analyzed by an independent core laboratory. Mean aortic valve gradients were obtained from the echocardiographic instrument's software system using planimetry of the Doppler spectral envelope. EOA was calculated automatically from the continuity equation by using the left ventricular outflow tract (LVOT) area and the time-velocity integral $(\mathrm{TVI})$ as $\mathrm{EOA}=\left(\mathrm{CSA}_{\mathrm{LVOT}} \times \mathrm{TVI}_{\mathrm{LVOT}}\right) / \mathrm{TVI}_{\mathrm{Ao}}$, where $\mathrm{CSA}_{\mathrm{LVOT}}$ is the cross-sectional area of $\mathrm{LVOT}$, $\mathrm{TVI}_{\mathrm{LVOT}}$ is the TVI of the LVOT derived from the pulsed-wave Doppler, and $\mathrm{TVI}_{\mathrm{Ao}}$ is the TVI of the aortic valve (Ao), derived from software integration of transvalvular continuous wave Doppler.

We defined any degree of PPM as EOAI $0.85 \mathrm{~cm}^{2} / \mathrm{m}^{2}$ or less and severe PPM as EOAI $0.65 \mathrm{~cm}^{2} / \mathrm{m}^{2}$ or less. Also, we compared overall adverse event rates of the 2 suture techniques.

\section{Statistical Analyses}

Unless otherwise noted, categoric variables are summarized as number and percentage, and continuous variables are summarized as mean \pm standard deviation. $P$ values are based on the chi-square test or Fisher exact test, when appropriate, for categoric variables, and a 2-sample $t$ test was used for continuous variables. No adjustments were made for multiple comparisons. Statistical analyses were generated using SAS software version 9.3 (SAS Institute Inc, Cary, NC).

\section{RESULTS}

A total of 393 patients with small aortic annuli underwent AVR with a 19-mm or 21-mm Trifecta valve bioprosthesis between August 2007 and November 2009. Of these 393 patients, 346 had 1-year echocardiographic examinations available for review.

Most (77.7\% [269/346]) of these patients were in group 1 (aortic valve prosthesis secured using noneverting pledgetreinforced mattress sutures); 70 of the 269 patients had received a $19-\mathrm{mm}$ prosthesis, and 199 patients had received a $21-\mathrm{mm}$ prosthesis. Of the 77 patients $(22.3 \%)$ in group 2 (aortic valve prosthesis implanted using everting mattress sutures or simple suture techniques), approximately more than one third $(\mathrm{n}=27)$ had received a $19-\mathrm{mm}$ prosthesis, whereas the rest $(\mathrm{n}=50)$ had received a $21-\mathrm{mm}$ prosthesis. The demographic characteristics of patients and their operative data are detailed in Table 1.

For patients who had received a 19-mm bioprosthesis, the peak and mean transvalvular gradients were similar for groups 1 and 2 (Table 2). However, there was a small but statistically significant difference in EOA that favored group $1(P<.05)$. In patients receiving the $21-\mathrm{mm}$ prosthesis, the peak and mean transvalvular gradients and the EOA and EOAI were similar between the 2 groups. Overall, the incidence of severe PPM was $12.8 \%$ $(31 / 243)$ in group 1 and $19.2 \%(14 / 73)$ in group 2 (Table 3). The rate of severe PPM (EOAI $<0.65 \mathrm{~cm}^{2} / \mathrm{m}^{2}$ ) in groups 1 and 2 was $18.6 \%(\mathrm{n}=11)$ and $25 \%(\mathrm{n}=6)$ for $19-\mathrm{mm}$ valves, respectively, and $10.9 \%(\mathrm{n}=20)$ and $16.3 \%(\mathrm{n}=8)$ for 21 -mm valves, respectively (Table 3$)$.

\section{DISCUSSION}

In patients undergoing AVR, supra-annular positioning facilitates implantation of a prosthesis of suitable size with adequate EOAI. However, even supra-annular valve replacement may result in sizeable transvalvular gradients, especially in patients with small annuli. Tabata and colleagues $^{4}$ recently reported that the method of securing the aortic prosthesis in the supra-annular position might affect hemodynamic performance. In their series of patients who underwent AVR with 19-mm or 21-mm CarpentierEdwards Perimount Magna bioprostheses, EOAs were greater in those patients who had simple sutures than in those who had noneverting pledget-reinforced mattress sutures. Tabata and colleagues ${ }^{4}$ hypothesized that noneverting sutures gathered tissue (and pledget material) beneath the valve, placing it in the pathway of blood flow.

Our findings do not support the notion that suture technique influences hemodynamic performance of small aortic valve bioprostheses. Indeed, there was not even a trend toward better hemodynamics in patients who had simple or everting sutures compared with the hemodynamics in patients with noneverting sutures. The explanation for the difference between our findings and those of Tabata and colleagues $^{4}$ is not immediately clear. In this series, all patients received the Trifecta bioprosthesis. The hemodynamic profile of this valve is good, as reflected by the average mean gradient in our patients of $10.6 \mathrm{~mm} \mathrm{Hg}$ 
TABLE 1. Characteristics of 346 patients with aortic valve replacement by valve size and suture technique*

\begin{tabular}{|c|c|c|c|c|c|c|}
\hline \multirow[b]{2}{*}{ Characteristic } & \multicolumn{3}{|c|}{ 19-mm prosthesis } & \multicolumn{3}{|c|}{ 21-mm prosthesis } \\
\hline & $\begin{array}{c}\text { Group 1: } \\
\text { Noneverting } \\
\text { suture }(\mathbf{n}=\mathbf{7 0})\end{array}$ & $\begin{array}{c}\text { Group 2: } \\
\text { Everting/simple } \\
\text { suture }(\mathbf{n}=\mathbf{2 7})\end{array}$ & $P$ value & $\begin{array}{c}\text { Group 1: } \\
\text { Noneverting } \\
\text { suture }(\mathbf{n}=\mathbf{1 9 9})\end{array}$ & $\begin{array}{c}\text { Group 2: } \\
\text { Everting/simple } \\
\text { suture }(\mathbf{n}=\mathbf{5 0})\end{array}$ & $P$ value \\
\hline Age, mean $\pm \mathrm{SD}, \mathrm{y}$ & $78.1 \pm 7.9$ & $76.5 \pm 7.1$ & .34 & $74.6 \pm 8.5$ & $74.9 \pm 7.6$ & .80 \\
\hline Female sex & $67(95.7)$ & $27(100)$ & .56 & $120(60.3)$ & $30(60)$ & .97 \\
\hline NYHA class III/IV & $42(60.0)$ & $19(70.4)$ & .34 & $103(51.8)$ & $28(56)$ & .59 \\
\hline Previous CVS procedure & $17(24.3)$ & $8(29.6)$ & .59 & $36(18.1)$ & $16(32)$ & .03 \\
\hline History of CAD & $44(62.9)$ & $18(66.7)$ & .73 & $102(51.3)$ & $31(62)$ & .17 \\
\hline Hypertension & $59(84.3)$ & $24(88.9)$ & .56 & $163(81.9)$ & $44(88)$ & .30 \\
\hline Diabetes mellitus & $15(21.4)$ & $4(14.8)$ & .46 & $57(28.6)$ & $10(20)$ & .22 \\
\hline Smoking history & $27(38.6)$ & $8(29.6)$ & .41 & 99 (49.7) & $25(50)$ & .97 \\
\hline Isolated AVR & $34(48.6)$ & $15(55.6)$ & .54 & $94(47.2)$ & $14(28)$ & .01 \\
\hline Concomitant CABG & $26(37.1)$ & $8(29.6)$ & .49 & $68(34.2)$ & $21(42)$ & .30 \\
\hline $\mathrm{CPB}$ time, mean $\pm \mathrm{SD}$, min & $102.7 \pm 49.1$ & $109.3 \pm 48.5$ & .56 & $105.8 \pm 48.3$ & $115.6 \pm 43.4$ & .19 \\
\hline $\mathrm{CPB}$ only AVR time, mean $\pm \mathrm{SD}$, min & $79.9 \pm 32.8$ & $87.3 \pm 42.3$ & .51 & $88.2 \pm 32.9$ & $76.4 \pm 40.8$ & .23 \\
\hline ACC time, mean $\pm \mathrm{SD}$, min & $79.8 \pm 38.3$ & $83.1 \pm 36.6$ & .70 & $80.1 \pm 36.6$ & $87.9 \pm 33.3$ & .17 \\
\hline ACC only AVR time, mean $\pm \mathrm{SD}$, min & $61.7 \pm 23.0$ & $67.6 \pm 34.6$ & .48 & $66.3 \pm 24.1$ & $56.1 \pm 26.0$ & .15 \\
\hline
\end{tabular}

$A C C$, Aortic crossclamp; $A V R$, aortic valve replacement; $C A B G$, coronary artery bypass grafting; $C A D$, coronary artery disease; $C P B$, cardiopulmonary bypass; CVS, cardiovascular surgery; NYHA, New York Heart Association; $S D$, standard deviation. *Values are mean \pm SD or number (percentage) unless indicated otherwise.

and $8.6 \mathrm{~mm} \mathrm{Hg}$ for $19-\mathrm{mm}$ and 21-mm prostheses, respectively, and these results are similar to those reported recently by Dell'Aquila and colleagues ${ }^{6}$ and Permanyer and colleagues. ${ }^{7}$ The EOAs in group $2(n=77)$ in our study are generally similar to those of patients who had simple suture techniques as reported by Tabata and colleagues ${ }^{4}$ (Figure 1), but the EOAIs were lower, probably because of the higher body surface area of the patients in our Western population.

The Trifecta valve is a newer bioprosthesis with favorable hemodynamics, and it is possible that some aspect

TABLE 2. Comparison of echocardiographic findings in 346 patients 1 year after aortic valve replacement by valve size and suture technique*

\begin{tabular}{|c|c|c|c|}
\hline Variable & $\begin{array}{c}\text { Group 1: } \\
\text { Noneverting } \\
\text { suture }\end{array}$ & $\begin{array}{c}\text { Group 2: } \\
\text { Everting/simple } \\
\text { suture }\end{array}$ & $P$ value \\
\hline Overall & $(\mathrm{n}=269)$ & $(\mathrm{n}=77)$ & \\
\hline Peak gradient, $\mathrm{mm} \mathrm{Hg}$ & $17.2 \pm 7.2$ & $18.4 \pm 7.4$ & 21 \\
\hline Mean gradient, $\mathrm{mm} \mathrm{Hg}$ & $8.9 \pm 3.9$ & $9.6 \pm 4.1$ & .16 \\
\hline $\mathrm{EOA}, \mathrm{cm}^{2}$ & $1.53 \pm 0.3$ & $1.42 \pm 0.3$ & .004 \\
\hline EOAI, $\mathrm{cm}^{2} / \mathrm{m}^{2}$ & $0.86 \pm 0.2$ & $0.8 \pm 0.2$ & .007 \\
\hline Valve size $19 \mathrm{~mm}$ & $(\mathrm{n}=70)$ & $(\mathrm{n}=27)$ & \\
\hline Peak gradient, $\mathrm{mm} \mathrm{Hg}$ & $19.5 \pm 8.3$ & $20.5 \pm 7.7$ & .59 \\
\hline Mean gradient, $\mathrm{mm} \mathrm{Hg}$ & $10.4 \pm 4.7$ & $11.1 \pm 4.4$ & .498 \\
\hline $\mathrm{EOA}, \mathrm{cm}^{2}$ & $1.40 \pm 0.3$ & $1.25 \pm 0.2$ & .01 \\
\hline EOAI, $\mathrm{cm}^{2} / \mathrm{m}^{2}$ & $0.84 \pm 0.2$ & $0.74 \pm 0.1$ & .01 \\
\hline Valve size $21 \mathrm{~mm}$ & $(\mathrm{n}=199)$ & $(\mathrm{n}=50)$ & \\
\hline Peak gradient, $\mathrm{mm} \mathrm{Hg}$ & $16.4 \pm 6.6$ & $17.2 \pm 7.1$ & .44 \\
\hline Mean gradient, $\mathrm{mm} \mathrm{Hg}$ & $8.4 \pm 3.5$ & $8.8 \pm 3.6$ & .45 \\
\hline $\mathrm{EOA}, \mathrm{cm}^{2}$ & $1.57 \pm 0.3$ & $1.50 \pm 0.3$ & .12 \\
\hline EOAI, $\mathrm{cm}^{2} / \mathrm{m}^{2}$ & $0.86 \pm 0.2$ & $0.83 \pm 0.1$ & .20 \\
\hline
\end{tabular}

EOA, Effective orifice area; $E O A I$, effective orifice area index. *Values are mean $\pm \mathrm{SD}$ unless indicated otherwise. of valve design may account for differences between our results and those of Tabata and colleagues. ${ }^{4}$ In the comparison of the Trifecta prosthesis with the Perimount Magna and Magna Ease prostheses (Edwards Lifesciences Corp, Irvine, Calif), Wendt and colleagues ${ }^{8}$ reported slightly lower mean gradients and higher aortic valve areas with the Trifecta prosthesis. However, multivariate covariance analysis showed no influence of prosthesis type on mean pressure gradient or aortic valve area because of differences in preoperative characteristics of the patients.

The design of our investigation differed slightly from that used by Tabata and colleagues, ${ }^{4}$ who compared only noneverting pledget-reinforced sutures and simple interrupted sutures. In contrast, we compared noneverting pledget-reinforced sutures with everting mattress sutures or simple sutures, because simple sutures were used in

TABLE 3. Distribution of prosthesis-patient mismatch at 1 year by valve size and suture technique*

\begin{tabular}{|c|c|c|c|}
\hline Prosthesis-patient mismatch & $\begin{array}{c}\text { Group 1: } \\
\text { Noneverting } \\
\text { suture }\end{array}$ & $\begin{array}{c}\text { Group 2: } \\
\text { Everting/simple } \\
\text { suture }\end{array}$ & $P$ value \\
\hline Overall & $(\mathrm{n}=243)$ & $(n=73)$ & \\
\hline $\mathrm{EOAI} \leq 0.85 \mathrm{~cm}^{2} / \mathrm{m}^{2}$ & $121(49.8)$ & $47(64.4)$ & .03 \\
\hline EOAI $\leq 0.65 \mathrm{~cm}^{2} / \mathrm{m}^{2}$ & $31(12.8)$ & $14(19.2)$ & .17 \\
\hline Valve size $19 \mathrm{~mm}$ & $(\mathrm{n}=59)$ & $(\mathrm{n}=24)$ & \\
\hline EOAI $\leq 0.85 \mathrm{~cm}^{2} / \mathrm{m}^{2}$ & $30(50.8)$ & $20(83.3)$ & .006 \\
\hline EOAI $\leq 0.65 \mathrm{~cm}^{2} / \mathrm{m}^{2}$ & $11(18.6)$ & $6(25.0)$ & .52 \\
\hline Valve size $21 \mathrm{~mm}$ & $(\mathrm{n}=184)$ & $(n=49)$ & \\
\hline $\mathrm{EOAI} \leq 0.85 \mathrm{~cm}^{2} / \mathrm{m}^{2}$ & $91(49.5)$ & $27(55.1)$ & .48 \\
\hline EOAI $\leq 0.65 \mathrm{~cm}^{2} / \mathrm{m}^{2}$ & $20(10.9)$ & $8(16.3)$ & .30 \\
\hline
\end{tabular}

EOAI, Effective orifice area index. *Values are number (percentage) unless indicated otherwise. 

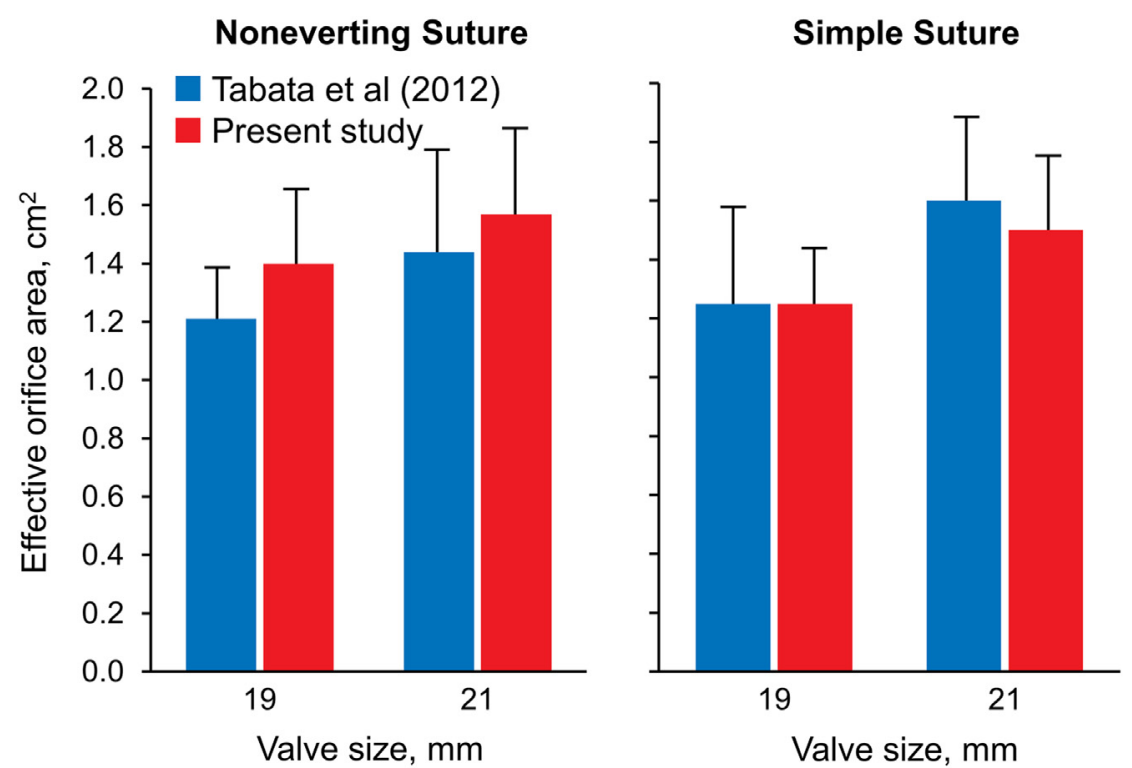

FIGURE 1. Comparison of EOAs 1 year postoperatively in the present study with EOAs reported by Tabata and colleagues. ${ }^{4}$ Bars represent 1 standard deviation, and data are grouped by suture method and valve size.

relatively few patients. The everting mattress technique avoids bunching tissue beneath the valve, as does the simple suture technique. Indeed, before combining patients who had simple sutures with patients who had everting sutures in the same group, we performed a preliminary analysis and found almost identical early and 1-year hemodynamic results (Table 4). Thus, we believe that combining these patients is justified.

Although the impact of PPM on AVR outcomes has been debated, ${ }^{9}$ several authors have concluded that it is an important predictor of long-term mortality and morbidity, and thus may be an especially important consideration in young athletic patients and in patients with poor ventricular function. ${ }^{10-15}$ PPM may predispose to early failure of bioprostheses because of stenosis, ${ }^{16}$ and in severe PPM, higher transvalvular gradients impair left ventricular mass regression. ${ }^{3,10}$ Our findings indicate that suture technique does not affect the risk of PPM in patients undergoing AVR with the small Trifecta aortic valve bioprosthesis.

Over time, endothelialization of the valve sewing ring may occur, with the potential for fibrous ingrowth from the ventricular aspect that may reduce the EOA. Theoretically, this process may be initiated or accelerated by pledget material in the subaortic region. We found no evidence of this in Doppler echocardiographic data obtained 1 year postoperatively; however, further followup of these patients will be important to determine whether there are any late deleterious effects of subaortic pledgets in patients with small prostheses.

A potential advantage of using a continuous suture technique or a nonpledgeted suture technique is the potential ability to accommodate a slightly larger diameter valve. Several series have demonstrated good results for this strategy, with low risk of perivalvular leakage., $3,17-20$ Likewise, when pledgets are used, the noneverting suture

TABLE 4. Comparison of simple and everting simple suture techniques at 1 year postoperatively*

\begin{tabular}{|c|c|c|c|}
\hline $\begin{array}{c}\text { Prosthesis-patient } \\
\text { mismatch }\end{array}$ & $\begin{array}{l}\text { Group 2A: } \\
\text { Simple } \\
\text { suture }\end{array}$ & $\begin{array}{c}\text { Group 2B: } \\
\text { Everting } \\
\text { pledget-reinforced } \\
\text { suture } \\
\end{array}$ & $P$ value \\
\hline Overall & $(\mathrm{n}=32)$ & $(\mathrm{n}=20)$ & \\
\hline Mean gradient, $\mathrm{mm} \mathrm{Hg}$ & $9.9 \pm 4.0$ & $10.1 \pm 4.7$ & .92 \\
\hline $\mathrm{EOA}, \mathrm{cm}^{2}$ & $1.4 \pm 0.27$ & $1.43 \pm 0.29$ & .71 \\
\hline $\begin{array}{c}\text { EOAI } \leq 0.85 \mathrm{~cm}^{2} / \mathrm{m}^{2}, \\
\text { No./total }(\%)\end{array}$ & $24 / 30(80)$ & $13 / 20(65)$ & .24 \\
\hline $\begin{array}{c}\text { EOAI } \leq 0.65 \mathrm{~cm}^{2} / \mathrm{m}^{2}, \\
\text { No./total }(\%)\end{array}$ & $7 / 30(23.3)$ & $6 / 20(30)$ & .24 \\
\hline Valve size $19 \mathrm{~mm}$ & $(\mathrm{n}=15)$ & $(\mathrm{n}=4)$ & \\
\hline Mean gradient, $\mathrm{mm} \mathrm{Hg}$ & $11.2 \pm 4.4$ & $11.4 \pm 6.6$ & .94 \\
\hline $\mathrm{EOA}, \mathrm{cm}^{2}$ & $1.24 \pm 0.22$ & $1.25 \pm 0.04$ & .94 \\
\hline $\begin{array}{c}\text { EOAI } \leq 0.85 \mathrm{~cm}^{2} / \mathrm{m}^{2}, \\
\text { No./total }(\%)\end{array}$ & $13 / 14(92.9)$ & $4 / 4(100)$ & $>.99$ \\
\hline $\begin{array}{c}\text { EOAI } \leq 0.65 \mathrm{~cm}^{2} / \mathrm{m}^{2}, \\
\text { No./total }(\%)\end{array}$ & 4/14 (28.6) & $1 / 4(25)$ & $>.99$ \\
\hline Valve size $21 \mathrm{~mm}$ & $(\mathrm{n}=17)$ & $(\mathrm{n}=16)$ & \\
\hline Mean gradient, $\mathrm{mm} \mathrm{Hg}$ & $8.8 \pm 3.4$ & $9.7 \pm 4.3$ & .51 \\
\hline $\mathrm{EOA}, \mathrm{cm}^{2}$ & $1.53 \pm 0.24$ & $1.47 \pm 0.30$ & .54 \\
\hline $\begin{array}{c}\text { EOAI } \leq 0.85 \mathrm{~cm}^{2} / \mathrm{m}^{2}, \\
\text { No./total }(\%)\end{array}$ & $11 / 16(68.8)$ & $9 / 16(56.2)$ & .47 \\
\hline $\begin{array}{c}\text { EOAI } \leq 0.65 \mathrm{~cm}^{2} / \mathrm{m}^{2}, \\
\text { No./total }(\%)\end{array}$ & $3 / 16(18.8)$ & $5 / 16(31.2)$ & .69 \\
\hline
\end{tabular}

$E O A$, Effective orifice area; EOAI, effective orifice area index. *Values are mean $\pm \mathrm{SD}$ or number/total (percentage) unless indicated otherwise. 
technique results in a supra-annular position and may allow a larger size valve than that achieved with the everting technique, which places the valve sewing ring within the annulus. Advocates of simple sutures point out that the technique does not require porous felt pledgets and multiple knots that can aid bacterial growth ${ }^{21,22}$ and further diminish the risk of thrombosis and embolus. ${ }^{17-19,22}$ However, other surgeons contend that pledget-reinforced mattress sutures decrease the risk of paravalvular leakage compared with that with simple or continuous sutures. ${ }^{23}$ Indeed, in a multicenter report by Englberger and colleagues, ${ }^{24}$ the risk of paravalvular leak was $1.7 \%(11 / 635)$ in patients with valves implanted with pledgeted mattress sutures, compared with 5.8\% (10/172) in patients with other suture methods, and multivariate analysis showed suture technique to be independently predictive of paravalvular leak. Our study was relatively small, with follow-up data available for only 1 year, but we found no differences in the risk of paravalvular leakage by surgical method. The single case of major paravalvular leak occurred in a patient in whom noneverting pledget-reinforced sutures were used.

\section{CONCLUSIONS}

In patients with small aortic annuli, AVR can be safely performed with noneverting pledget-reinforced sutures, with results (ie, similar early postoperative gradients, valve orifice areas, and rates of PPM) comparable to those of other suture techniques.

\section{References}

1. Totaro P, Degno N, Zaidi A, Youhana A, Argano V. Carpentier-Edwards PERIMOUNT Magna bioprosthesis: a stented valve with stentless performance? J Thorac Cardiovasc Surg. 2005;130:1668-74.

2. Sievers HH. Prosthetic aortic valve replacement. J Thorac Cardiovasc Surg. 2005;129:961-5.

3. Petracek MR. Assessing options for the small aortic root. J Heart Valve Dis. 2002;11(Suppl 1):S50-5.

4. Tabata M, Shibayama K, Watanabe H, Sato Y, Fukui T, Takanashi S. Simple interrupted suturing increases valve performance after aortic valve replacement with a small supra-annular bioprosthesis. J Thorac Cardiovasc Surg. 2014;147: $321-5$.

5. Bavaria JE, Desai ND, Cheung A, Petracek MR, Groh MA, Borger MA, et al. The St Jude Medical Trifecta aortic pericardial valve: results from a global, multicenter, prospective clinical study. J Thorac Cardiovasc Surg. 2013 [Epub ahead of print].

6. Dell'Aquila AM, Schlarb D, Schneider SR, Sindermann JR, Hoffmeier A, Kaleschke G, et al. Clinical and echocardiographic outcomes after implantation of the Trifecta aortic bioprosthesis: an initial single-centre experience. Interact Cardiovasc Thorac Surg. 2013;16:112-5.

7. Permanyer E, Estigarribia AJ, Ysasi A, Herrero E, Semper O, Llorens R. St. Jude Medical Trifecta ${ }^{\mathrm{TM}}$ aortic valve perioperative perfor- mance in 200 patients. Interact Cardiovasc Thorac Surg. 2013 [Epub ahead of print].

8. Wendt D, Thielmann M, Plicht B, Assmann J, Price V, Neuhauser M, et al. The new St Jude Trifecta versus Carpentier-Edwards Perimount Magna and Magna Ease aortic bioprosthesis: is there a hemodynamic superiority? J Thorac Cardiovasc Surg. 2013 [Epub ahead of print].

9. Jamieson WR, Ye J, Higgins J, Cheung A, Fradet GJ, Skarsgard P, et al Effect of prosthesis-patient mismatch on long-term survival with aortic valve replacement: assessment to 15 years. Ann Thorac Surg. 2010;89: $51-8$.

10. Mohty D, Malouf JF, Girard SE, Schaff HV, Grill DE, Enriquez-Sarano ME et al. Impact of prosthesis-patient mismatch on long-term survival in patients with small St. Jude Medical mechanical prostheses in the aortic position. Circulation. 2006;113:420-6. Erratum in: Circulation. 2007;115:e639 Mohty-Echahidi, Dania [corrected to Mohty, Dania.].

11. Tasca G, Mhagna Z, Perotti S, Centurini PB, Sabatini T, Amaducci A, et al Impact of prosthesis-patient mismatch on cardiac events and midterm mortality after aortic valve replacement in patients with pure aortic stenosis. Circulation 2006;113:570-6. Erratum in: Circulation. 2006;113:e288. Quiani, Eugenio [corrected to Quaini, Eugenio].

12. Walther T, Rastan A, Falk V, Lehmann S, Garbade J, Funkat AK, et al. Patient prosthesis mismatch affects short- and long-term outcomes after aortic valve replacement. Eur J Cardiothorac Surg. 2006;30:15-9.

13. Daneshvar SA, Rahimtoola SH. Valve prosthesis-patient mismatch (VP-PM): a long-term perspective. J Am Coll Cardiol. 2012;60:1123-35.

14. Head SJ, Mokhles MM, Osnabrugge RL, Pibarot P, Mack MJ, Takkenberg JJ, et al. The impact of prosthesis-patient mismatch on long-term survival after aortic valve replacement: a systematic review and meta-analysis of 34 observational studies comprising 27186 patients with 133141 patient-years. Eur Heart J. 2012;33:1518-29.

15. Bleiziffer S, Eichinger WB, Hettich I, Guenzinger R, Ruzicka D, Bauernschmitt R, et al. Prediction of valve prosthesis-patient mismatch prior to aortic valve replacement: which is the best method? Heart. 2007;93: 615-20.

16. Flameng W, Herregods MC, Vercalsteren M, Herijgers P, Bogaerts K, Meuris B. Prosthesis-patient mismatch predicts structural valve degeneration in bioprosthetic heart valves. Circulation. 2010;121:2123-9.

17. Qicai H, Zili C, Zhengfu H, Weiming Z, Zhoumiao C, Dingsheng Y, et al Continuous-suture technique in aortic valve replacement. J Card Surg. 2006 21:178-81.

18. Watanabe G, Ushijima T, Tomita S, Yamaguchi S, Koshida Y, Iino K. Revival of continuous suture technique in aortic valve replacement in patient with aortic valve stenosis: a novel modified technique. Innovations (Phila). 2011;6:311-5.

19. Cleland J. A universally applicable continuous suture technique for insertion of aortic valve prostheses. Ann Thorac Surg. 1975;19:719-24.

20. LaPar DJ, Ailawadi G, Bhamidipati CM, Singh M, Dare D, Kern JA, et al. Use of a nonpledgeted suture technique is safe and efficient for aortic valve replacement. J Thorac Cardiovasc Surg. 2011;141:388-93.

21. Cooley DA. Simplified techniques of valve replacement. J Card Surg. 1992;7 357-62.

22. Doty DB, Nelson RM. Aortic valve replacement: continuous-suture technique J Card Surg. 1986;1:379-82.

23. Nair SK, Bhatnagar G, Valencia O, Chandrasekaran V. Effect of valve suture technique on incidence of paraprosthetic regurgitation and 10-year survival. Ann Thorac Surg. 2010;89:1171-9.

24. Englberger L, Schaff HV, Jamieson WR, Kennard ED, Im KA, Holubkov R, et al; AVERT Investigators. Importance of implant technique on risk of major paravalvular leak (PVL) after St. Jude mechanical heart valve replacement: a report from the Artificial Valve Endocarditis Reduction Trial (AVERT). Eur J Cardiothorac Surg. 2005;28:838-43. 